Journal of Economic Theory 6(1): 1-13, 2012

ISSN: 1994-8212

(C) Medwell Journals, 2012

\title{
Has the Change in Central Bank Autonomy Legislation Altered the Monetary Transmission Channels in Nigeria?
}

\author{
${ }^{1}$ Raheem Abiodun Najeem and ${ }^{2}$ Olowookere Emmanuel Afolabi \\ ${ }^{1}$ Department of Economics, Lead City University, Ibadan, Nigeria \\ ${ }^{2}$ Department of Economics, University of Ibadan, Ibadan, Nigeria
}

\begin{abstract}
The transmission process has been observed to vary over different economies of different financial structure and Central Bank autonomy. This study examines the various monetary transmission channels in Nigeria; brief allusion is $1998 \mathrm{CBN}$ Act as a source of changes in the channels. The study then goes ahead to compare the transmission process in the period when the $1991 \mathrm{CBN}$ Act is operational and the period when the 1998 CBN Act is implemented, the latter period been the one when the bank has higher autonomy. Preliminary analysis shows a rising trend for all variables but interest rate and net export. The results of the VAR analysis and variance decomposition tests show that there is no significant change in the monetary transmission channels between the two periods. The major channel identified is the credit channel and although this channel becomes stronger in the second period, researchers cannot statistically distinguish the process of monetary transmission based on the autonomy granted the Central Bank of Nigeria.
\end{abstract}

Key words: Central Bank autonomy, monetary transmission mechanism, channel, economic variables, interest rate, Nigeria

\section{INTRODUCTION}

While the battle for superiority between the Keynesians and their age long opponent in the field of economics, the Monetarists remains partially resolved due to restricted information available to the past and present generations of economists, some facts had been laid to rest. One of such issues is the fact that monetary policy affects the real economic variables and in fact, goes a long way in determining their magnitude, at least in the short run. This is why, Mishkin $(1995,1996)$ succinctly states that both economists and politicians have been heard to advocate in recent years that the stabilization of output and inflation be left to monetary policy.

According to him, monetary policy is now at the centre stage in discussions about how to promote sustainable growth and low inflation in the economy. Fiscal policy has lost its luster since its heydays in the 1960 s, partly because of concern over persistently large budget deficits and partly because of doubts that the political system can make tax spending decisions in a timely way to achieve desirable stabilization outcomes. Meanwhile, monetary policy has been ever more at the centre of macroeconomic policymaking. Long before this statement, Mann (1969) concluded based on his observations on empirical studies that money matters in handling macroeconomic problems and that financial variables play importants role in the economy. Monetary policy involves credit and financial policies used in changing money supply and/or interest rate so as to regulate or modify the economic affairs of a country in keeping with certain objectives. Like other broad macroeconomic policies, the sector non-specific feature of monetary policy implies that it can affect several sectors of the economy in varying directions and magnitude. Given the dynamic complexity of the contemporary economies; knowledge of the channels and outcomes of monetary policy change is necessary (BIS, 1998). In other words, the abilities to characterize these channels and outcomes give impetus to the formulation of appropiate relevant monetary policy, understand the likely channels of operation, determine the optimal magnitude of policy change and effective coordination of these channels to achieve desired objectives.

Several channels through which monetary policy permeates the economy have been identified and established in the literature (Mishkin, 1995). Also identified is the fact that monetary transmission mechanism depends among others on changes in the structure of an economy, future policy expectation, objective and independence of the Central Bank (BIS, 1998). Uncertainty about monetary transmission mechanic may make way for misapplication of monetary policy thereby ultimately leading to the notion of

Corresponding Author: Raheem Abiodun Najeem, Department of Economics, Lead City University, Ibadan, Nigeria 
multiplication of uncertainty (Brainard, 1967). The idea that a complete story of the monetary transmission mechanism should include a description of the central banks' policy rules (Taylor, 1995) is plausible as this allows us to examine the efficiency of policy regimes. It should be recalled that the Central Bank of Nigeria, CBN (Amendment) Decree No. 37 of 1998 and Banks and other Financial Institution, BOFI (Amendment) Decree No. 38 of 1998 allows the CBN more autonomy than ever before in carrying out its operations. This law amendment was necessitated given the large macroeconomic instability witnessed under the former CBN Decree No. 24 of 1991 (Ojo, 1999; CBN, 1999).

There is a growing body of literature trying to validate the hypothesis that Central Bank's autonomy engenders macroeconomic stability (Pollard, 1993). In other words if Central Bank autonomy has the potential of changing the macroeconomic stability structure and monetary policy instrument is in the hands of the Central Bank (Ojo, 1999), it may then imply that the channels through which monetary policy transmits to other sectors of the economy are altered.

From the foregoing, this research sets out to identify the monetary transmission channels in Nigeria and examine if and how higher independence of the CBN has any impact on the channels. There is the need to carry out the research because other researches in this direction do not explicitly document the effect of policy change on monetary channels. The approach in this study differs from previous researches in that researchers consider the impact of a change in policy directed at $\mathrm{CBN}$ as against a policy change like Structural Adjustment Programme (SAP) which is general.

Background to the study: In this background, researchers examine issues like monetary policy, exchange rate policy and laws guiding the operations of the Central Bank of Nigeria. Researchers also discuss the effect of these factors on the behaviour of some monetary variables over time.

Monetary policy in Nigeria: Monetary policy involves the use of interest rates or controls on the money supply to influence the economy in terms of desired level or rate of growth in real activity, the price level, the exchange rate or the balance of payments (Black, 2002). Monetary policy in Nigeria is the prerogative of Central Bank of Nigeria (CBN) and it does so through its annual memorandum having analysed the current economic situations and projecting into the future (Nnanna, 2002). In the pre-SAP era (before 1986), direct monetary instruments like fixed interest and exchange rates, credit ceilings selective credit controls and special deposits were mainly used by the monetary authority (Odusola and Akinlo, 2001). As time went on, it became evident that the CBN could not sustain its objective of maintaining internal and external balance due to these facts among others:

- Implementation of credit ceilings became less effective

- Fixed interest rates were low and therefore this encourages monetary expansion and also stunted private savings

- Fixed exchange rate also encouraged importation and discouraged exports and this led to balance of payments deterioration especially in the face of falling oil revenue

The above as well as other imperfections in the economy, led to the adoption of the Structural Adjustment Programme (SAP) in July, 1986. Although, this has not significantly altered the role of the CBN, emphasis on the appropriate monetary instruments has markedly changed to those engendering a market-oriented financial system. Table 1 shows a summary of some important policy steps taken by the monetary authority durin the period.

Review of literature: Monetary transmission mechanism can be defined as dynamic adjustments of output and other macroeconomic variables to monetary policy. The identification of channels through which these adjustments operate is crucial for relevant policy making. In an open-macroeconomic framework, channels like interest rate, exchange rate, equity price and credit are identified in the literature. The discussions here draw from Mishkin (1995) and this serves as the theoretical framework for the present study.

\section{Theoretical review}

Interest rate channels: Following a monetary expansion, real interest rate falls which in turn lowers the cost of capital, causing a rise in investment spending, thereby leading to an increase in aggregate demand and a rise in output. This schematic linkage is shown as:

Where:

$$
\mathrm{M} \Delta \rightarrow \mathrm{r} \nabla \rightarrow \mathrm{I} \Delta \rightarrow \mathrm{Y} \Delta
$$

$\mathrm{m}=$ Money supply

$\mathrm{r}=$ Real interest rate

$\mathrm{I}=$ Investment

$\mathrm{Y}=$ Output

Exchange rate channel: Monetary expansion leads to a fall in interest rate which in turn makes capital inflow less 
Table 1: Monetary and exchange rate policies over time

\begin{tabular}{ll}
\hline Purposes & Measures \\
\hline Liquidity management & The reduction in the maximum ceiling on credit growth allowed for banks \\
& The recall of the deposit requirement against outstanding external payment arrears to CBN from banks \\
Abolition of the use of foreign guarantees/currency deposits collaterals for naira loans & Withdrawal of public sector deposits from banks to the CBN \\
& Increase in commercial bank cash reserve requirement in 1990, 1992,1996 and 1999 \\
Efficiency and flexibility in banks & Sector specific credit distribution targets were compressed into 4 sectors in 1986, 2 in 1987 and none in 1996
\end{tabular}

credit operations

Re-capitalisation
Increase in minimum paid-up capital of commercial and merchant banks in 1990 to N50 million and N40 million from N20 million and N12 million respectively and to N500 in 1997

Enforcement of risk-weighted measure of capital adequacy recommended by the Basle committee of the Bank of International settlement in 1990

CBN encourages merger and acquisitions

In 1998, the paid-up capital of banks was increased to N500 million, N26 billion in 2001 and N256 in 2004

Open market operation

3 disc ount houses were opened in March, 1993, one in 1995 and another one in 1996 on 30th June 1993, the CBN commenced OMO in treasury securities with banks through discount houses on a weekly basis

Exchange rate policies

In September, 1986, a flexible exchange rate mechanism was adopted with the floating of the naira in the Second-Tier Foreign Exchange (SFEM) market

The 1st and 2nd-tier markets were merged into an enlarged Foreign Exchange Market (FEM) in July, 1987 In 1988, the inter-bank market where banks transact official foreign exchange was separated from official market and an autonomous market for privately sourced foreign exchange emerged with its independent rates To further reduce exchange rate instability, the CBN modified the inter-bank procedure in December 1990 when the DAS was re-introduced while in August 1991 the bank introduced the modal weighted average method of exchange rate determination

As a result of high premium accrued to the parallel market, a completely deregulated system of foreign exchange was introduced in 1992

In 1994, the naira exchange rate was fixed at N21.9960 to the US dollar

Dual exchange rate policy was introduced in 1995

In 1997, the policy thrust of guided deregulation through the AFEM was retained with some adjustments

To deepen the market the Inter-Bank Foreign Exchange Market (IFEM) was introduced in 1999

Failure of foreign exchange to impact adequately on the real sector of the economy, among others, led to the re-introduction of DAS in 2002 and this is still in use. Since its introduction, DAS has succeeded in narrowing the arbitrage premium from and ensure relative stability of the naira

CBN annual reports and statement of accounts (Various issues)

attractive, thus leads to the depreciation of the domestic currency value. Depreciation raises exports but reduces imports, thereby causing a rise in net exports and hence aggregate output:

$$
\mathrm{M} \Delta \rightarrow \mathrm{r} \nabla \rightarrow \mathrm{E} \nabla \rightarrow \mathrm{NX} \Delta \rightarrow \mathrm{Y} \Delta
$$

Where:

$$
\begin{aligned}
& \mathrm{M}=\text { Money supply } \\
& \mathrm{r}=\text { Real interest rate } \\
& \mathrm{E}=\text { Exchange rate } \\
& \mathrm{NX}=\text { Net exports } \\
& \mathrm{Y}=\text { Output }
\end{aligned}
$$

Equity price channels: There are two important channels here; the first is the Tobin's q Theory: Tobin's q measures the market value of firms as a ratio of the replacement cost of capital if $\mathrm{q}$ is high, the market price of firms is high relative to the replacement cost of capital and new plant is cheap relative to the market value of business firms. Thus, investment spending will rise because firms can buy a lot of new investment goods with a small issue of equity. In the monetarist explanation, a rise in money supply raises the public demand for commodities, equity inclusive and this raises equity prices.

$$
\mathrm{M} \Delta \rightarrow \mathrm{P}_{\mathrm{e}} \Delta \rightarrow \mathrm{q} \Delta \rightarrow \mathrm{I} \Delta \rightarrow \mathrm{Y} \Delta
$$

A higher money supply leads to increase in demand for equity which in turn raises equity prices. A higher equity prices raises Tobin's q, investment and ultimately aggregate output. The higher stock prices can also work through the second channel known as the wealth effect. Here, higher stock prices lead to rise in the financial wealth, thus increasing the lifetime resources of consumers, consumption rises and so also is output:

$$
\mathrm{M} \Delta \rightarrow \mathrm{P}_{\mathrm{e}} \Delta \rightarrow \mathrm{W} \Delta \rightarrow \mathrm{C} \Delta \rightarrow \mathrm{Y} \Delta
$$

Where:

$\mathrm{P}_{\mathrm{e}}=$ Equity prices

$\mathrm{q}=$ Tobin's $\mathrm{q}$

$\mathrm{W}=$ Wealth

$\mathrm{C}=$ Consumption

Credit channels: This works mainly via the bank lending channel. An expansionary monetary policy which raises bank reserves and bank deposits will eventually increase loanable funds. This in turn raises investment and aggregate output: 


$$
\mathrm{M} \Delta \rightarrow \mathrm{D} \Delta \rightarrow \mathrm{L} \Delta \rightarrow \mathrm{I} \Delta \rightarrow \mathrm{Y} \Delta
$$

Where:

$\mathrm{D}=$ Bank deposit

$\mathrm{L}=$ Loans

Empirical review: This study reviews some researches in the area of monetary transmission mechanism. The result of Bernanke and Blinder (1992) using VAR Model on monthly data of the US economy provides support for credit channel which affects aggregate spending through bank loans (Philip et al., 2003) using Vector Error Correction on the economy of Ghana, finds the relevance of exchange rate channel (Agha et al., 2005) concluded by means of VAR Model on data from Pakistan that bank lending to private sector affects aggregate spending and prices (Table 2).

The data from Table 2 shows that studies from several economies identified various channels through which monetary policy transmits to the economy. Some of these findings are similar while others are different. Another feature of the studies is that Vector
Autoregressions Method is usually employed in studies of this nature. Finally, Table 2 shows a dearth of studies in this area on Nigeria and none has actually attempted to document changes in monetary transmission mechanism as a result of changes in a Central Bank's autonomy status which is the justification for the present study.

Study scope and data sources: This study utilises macroeconomic variables like broad money supply $\left(\mathrm{M}_{2}\right)$, minimum rediscount rate (r), total credit advancement to the private sector (Credit), exchange rate (E), net exports (NX) and real GDP (GDP). Quarterly data of all these variables are extracted from Central Bank of Nigeria statistical bulletin and annual reports and statement of account of various years.

The study covers the period of 1988-2007. This period sufficiently captures the two periods of 1991 and 1998 CBN Acts. All variables are used in their level forms in descriptives to enable easy comparisons. However in analytical procedures, all variables, except rates are expressed in their natural $\log$ forms prior to estimation.

Table 2: Summary of empirical literature

\begin{tabular}{|c|c|c|c|}
\hline Refrences & $\begin{array}{l}\text { Methodology, type } \\
\text { of data and scope }\end{array}$ & Variables used & Major finding \\
\hline Philip et al. (2003) & $\begin{array}{l}\text { Vector error correction } \\
\text { Quarterly data 1969:4. Ghana }\end{array}$ & $\begin{array}{l}\text { Inflation, real GDP, credit to } \\
\text { private sector, treasury bill rate }\end{array}$ & $\begin{array}{l}\text { Strong evidence of monetary policy } \\
\text { real exchange rate and broad money instrument } \\
\text { affecting price and real GDP. Supports exchange } \\
\text { rate channel }\end{array}$ \\
\hline Kevin (2006) & $\begin{array}{l}\text { VAR Model. Monthly } \\
\text { data: } 1997-205 \text {. Kenya }\end{array}$ & $\begin{array}{l}\text { Real GDP, CPI, money stock, } \\
\text { short-term interest rate and nominal } \\
\text { effective exchange rate }\end{array}$ & $\begin{array}{l}\text { Increase in interest rate leads to a fall in prices } \\
\text { and an appreciation of exchange rate but } \\
\text { accounting little for output fluctuation }\end{array}$ \\
\hline Helmut and Jurgen (2001) & $\begin{array}{l}\text { Macroeconomic Model (OLS } \\
\text { Estimation Technique) } \\
\text { Quarterly data. Germany }\end{array}$ & $\begin{array}{l}\text { M3, GNP, inflation rate, long term } \\
\text { interest rate, import price index }\end{array}$ & $\begin{array}{l}\text { Permanent increase in instrument interest rate } \\
\text { reduce inflation and output }\end{array}$ \\
\hline Uanguta and Ikhinde (2006) & $\begin{array}{l}\text { VAR Model. Monthly data: } \\
1990-1999 . \text { Namibia }\end{array}$ & $\begin{array}{l}\text { Private investment, credit to the private } \\
\text { sector, money supply, consumer price } \\
\text { index and lending rate }\end{array}$ & $\begin{array}{l}\text { Contractionary monetary policy increase lending } \\
\text { rate which decreases private investment and output. } \\
\text { Theresult also provide support for the bank lending } \\
\text { channel }\end{array}$ \\
\hline Agha et al. (2005) & $\begin{array}{l}\text { VAR Model. Monthly data: } \\
\text { July, 1996-March, } 2004 . \\
\text { Pakistan }\end{array}$ & $\begin{array}{l}\text { Credit to private sector, CPI, real } \\
\text { effective exchange rate, } 6 \text { months treasury } \\
\text { bill rate, industrial production index } \\
\text { and Karachi stock exchange rate }\end{array}$ & $\begin{array}{l}\text { Their result provides support for the bank lending } \\
\text { channel through lending to private sector which } \\
\text { affects aggregate spending and prices }\end{array}$ \\
\hline $\begin{array}{l}\text { Bernanke and } \\
\text { Gertler (1995) }\end{array}$ & $\begin{array}{l}\text { VAR Model. Monthly data } \\
\text { 1965:1-1984: IV Seasonally } \\
\text { adjusted. USA }\end{array}$ & $\begin{array}{l}\text { Real GNP, GNP price deflator, real } \\
\text { defence spending, MI money stock, } \\
\text { the monetary base, commercial } \\
\text { bank loans }\end{array}$ & $\begin{array}{l}\text { First, it appears that credit shocks are important } \\
\text { for output and second, however money and credit } \\
\text { are approximately equal important forces in the } \\
\text { monetary transmission mechanism }\end{array}$ \\
\hline $\begin{array}{l}\text { Dabla-Noris and } \\
\text { Floerkemeier ( } 2006)\end{array}$ & $\begin{array}{l}\text { VAR Model. Monthly data, } \\
\text { 2000:5-2005:12 Armenia }\end{array}$ & $\begin{array}{l}\text { Interest rate, exchange rate, money } \\
\text { supply, output inflation }\end{array}$ & $\begin{array}{l}\text { Shock to monetary aggregate affect output but } \\
\text { interest rate channel is weak }\end{array}$ \\
\hline Anil et al. (1993) & $\begin{array}{l}\text { Structural model quarterly data, } \\
\text { 1963: 1-1989: IV. USA }\end{array}$ & $\begin{array}{l}\text { Commercial paper; commercial bank } \\
\text { loans; bank loans as a fraction of total } \\
\text { short-term external finance; the spread } \\
\text { between prime commercial paper rates } \\
\text { and TBR; Investment and inventory } \\
\text { data: business cycle indicators }\end{array}$ & $\begin{array}{l}\text { The study finds that tighter monetary policy leads } \\
\text { to a shift in firms' mix of external financing: } \\
\text { commercial paper issuance rises while bank loans } \\
\text { fall. This suggests that contractionary policy reduce } \\
\text { loan supply, thus affect investment, interest rates } \\
\text { and output }\end{array}$ \\
\hline $\begin{array}{l}\text { Bernanke and } \\
\text { Blinder (1992) }\end{array}$ & $\begin{array}{l}\text { VAR Model monthly data } \\
\text { 1959:7-1989:12. USA }\end{array}$ & $\begin{array}{l}\text { Log of CPI; } \log \text { of } \mathrm{M} 1 \text { and } \mathrm{M} 2 \text {; federal } \\
\text { funds rate; } 3 \text { months TBR; } 10 \text { years } \\
\text { treasury bond rate; non borrowed } \\
\text { reserves of depository institutions }\end{array}$ & $\begin{array}{l}\text { Monetary policy works in part by affecting the } \\
\text { composition of bank asset, i.e., tight monetary } \\
\text { policy affects the supply of bank loans }\end{array}$ \\
\hline
\end{tabular}

Tarawalie (2008) 


\section{MATERIALS AND METHODS}

Descriptive analysis showing trend and structure and interdependence of monetary channels variables are initially explored. Given the interdependence among economic variables, connectivity among them can be represented by:

$$
y_{t}=A_{i} y_{t-1}+\ldots+A_{p} y_{t-p}+B x_{t} 1+\varepsilon_{t}
$$

Where:

$$
\begin{array}{ll}
y_{t} & \text { K vector of endogenous variables } \\
x_{t} & \text { d vector of exogenous variables } \\
A_{i}, \ldots, A_{p} \text { and } B= & \begin{array}{l}
\text { Matrices of the coefficient to be } \\
\text { estimated }
\end{array} \\
\varepsilon_{t} & \text { A vector of innovations }
\end{array}
$$

Equation 1 is usually estimated using Vector Autoregression (VAR) estimation which is commonly used in forecasting system of interrelated time series and for analysing the dynamic impact of random disturbances on the system of variables. It sidesteps the need for structural modelling by treating every endogenous variable in the system as a function of lagged values of all of the endogenous variables in the systems.

Variance Decomposition Method is also employed. It separates the variation in an endogenous variable into component shocks to the VAR. Since VAR estimates are subject to the lag length, researchers employ some criteria like FPE (Final Prediction Error), AIC (Akaike Information Criterion), Schwarz and Hannan-Quinn Information Criterion to choose the optimal lag length, also consider the presence of serial correlations in the choice model. Equation 1 is estimated as the monetary transmission mechanism model for the period 1988-2007; researchers also break the period into two judging by the 2 laws operational in these periods.

Further, Eq. 1 is estimated separately for each of the periods and the Hausman specification test is used in determining whether there is really a difference in the monetary channels between this two regulation regimes.

\section{RESULTS AND DISCUSSION}

The study presents the trend analyses of the variables of interest, comparison are made between the periods under which each of the laws operates in terms of the variables absolute values, ratios and their growth rates. Therefore, the VAR estimation of the monetary transmission mechanisms is estimated and discussions are made based on the VAR results and the Variance Decomposition test.
Trend analysis: Figure 1 shows a rising trend for most of the variables; except for interest rate and net export; also for most of these series, the period of sharp increase coincides with the period of the new Act of 1998. Interest rate is observed to oscillate between some high and low values during the period of study and the peak is around 1995 and a fall in its values is recorded in the latter part of the period during which the 1991 CBN Act was operational.

Just after the 1998 Act, interest rate continues to rise gradually, however a declining trend is observed recently. Net export on the other hand, records the all period highest values in the 1st years of transition to new political governance.

Macroeconomic performance differential following CBN autonomy: In capturing the macroeconomic performance changes following the change in $\mathrm{CBN}$ autonomy status (Table 3-5). From Table 3, it is observed that the average money supply in the 1991 Act period (N110.9b) is lower than that of 1998 Act period (N12522.5b) interest rate is lower in the second period, this is expected since money supply in this period is higher. Other variables like credit advancement to private sector, exchange rate, net export and real GDP are higher in the period of 1998 Law.

This does not necessarily imply better performance in the 1998 Act period as this period also witnessed higher average CPI level of 85.32. Thus, Table 4 and 5 on growth rates and ration analysis may be more informative. In Table 4 , the mean growth rate of $\mathrm{M}_{2}$ is actually higher (8.61\%) under the 1991 Law compared with $5.76 \%$ under 1998 Law. Less for real GDP and net export growth rate, the growth rates of other variables are also higher under the 1991 Law.

Hence, researchers can conclude that the higher growth rate of money supply under 1991 Act feeds into higher price level which simultaneously raises nominal interest rate and exchange rate, thereby leading to a poorer current account balance and consequently, the period's lower RGDP status.

Finally, Table 5 on ratio analysis and their growth rates corroborates the earlier findings as the ratios of money and credit to GDP are higher under 1998 CBN Act but their growth rates are higher under the 1991 Act.

Channels of monetary policy: The study presents the result of estimated equation for the entire period of 1988-2007 using quarterly data. This allows the identification of significant channels over the entire period. Also explored is the variance decomposition mechanics.

To address the second objective of this study, researchers break the period into 2 , according to the span of each CBN Act which therefore yields 10 years apiece and given the frequency of the data quarterly; these 


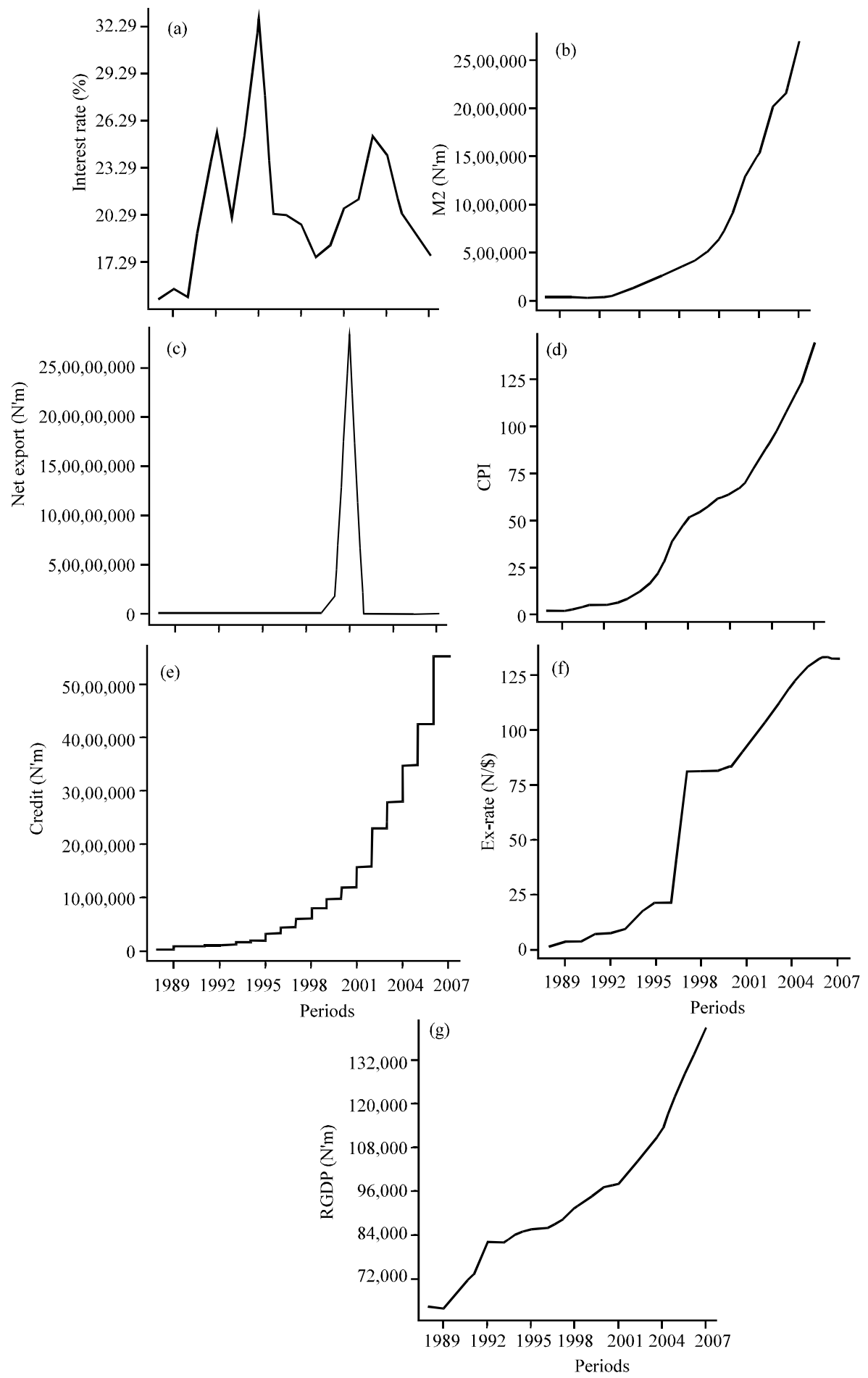

Fig. 1: Trend analysis

translate to 40 data points for each period. The results of the 2 periods are then juxtaposed for differences. VAR estimations are observed to be sensitive to their order of lags, thus prior to estimations. Table 6 is computed and it suggests through various criteria order 1 is the optimal lag length. Table 7 also justifies the choice of lag 1 as the LM test at this lag length suggests that there is no serial correlation.

Table 8 therefore presents the VAR estimates for the entire period. The results of an increase in money supply 
Table 3: Change in CBN Act and macroeconomic variables

\begin{tabular}{lllllllll}
\hline Regime & Units & M2 $(\mathrm{N} ' m)$ & Interest rate $(\%)$ & Credit (N'm) & CPI & Ex-rate (N/\$) & Net export (N'm) & RGDP (Nm) \\
\hline Under 1991 Law & Minimum & 15328.1 & 15 & 42073.4 & 1.9 & 1 & -20211.6 & 63338.69 \\
& Maximum & 318763.5 & 37.8 & 541364.2 & 45 & 83.6 & 95286.6 & 89248.21 \\
& Mean & 110911.8 & 21.1345 & 167548 & 11.455 & 17.82 & 14582.37 & 77980.46 \\
& Median & 67317.45 & 20.3 & 111278.3 & 5.85 & 8.85 & 5880 & 82093.91 \\
& N & 40 & 40 & 40 & 40 & 40 & 40 & 40 \\
Under 1998 Law & MD & 89260.24 & 5.7271 & 132117.5 & 11.9781 & 22.4763 & 23788.12 & 9027.653 \\
& Minimum & 328714.7 & 16.3 & 545563.5 & 47.4 & 79.1 & -6387986 & 90593.06 \\
& Maximum & 2814846 & 29.9 & 5975953 & 153.9 & 134.7 & $4.36 \mathrm{E}+08$ & 159193.4 \\
& Mean & 1252544 & 20.48 & 2354555 & 85.315 & 106.725 & 30613283 & 110170.5 \\
& Median & 1149620 & 19.85 & 1911233 & 74.6 & 106.95 & 424476.1 & 105499.2 \\
& N & 40 & 40 & 40 & 40 & 40 & 40 & 40 \\
Total & SD & 790429.7 & 2.8052 & 1593896 & 30.1288 & 20.6634 & 94213092 & 17538.16 \\
& Minimum & 15328.1 & 15 & 42073.4 & 1.9 & 1 & -6387986 & 63338.69 \\
& Maximum & 2814846 & 37.8 & 5975953 & 153.9 & 134.7 & $4.36 \mathrm{E}+08$ & 159193.4 \\
& Mean & 681728 & 20.8073 & 1261052 & 48.385 & 62.2725 & 15313933 & 94075.47 \\
& Median & 323739.1 & 20.2 & 543463.9 & 46.2 & 80.15 & 64947.5 & 89920.64 \\
& N & 80 & 80 & 80 & 80 & 80 & 80 & 80 \\
& SD & 801451.3 & 4.4928 & 1572792 & 43.5895 & 49.6107 & 67962554 & 21316.87 \\
\hline
\end{tabular}

Table 4: Change in growth rates

\begin{tabular}{lllllllll}
\hline Regime & Units & GR M2 (\%) & GR intr (\%) & GR credit (\%) & GR CPI (\%) & GR ex-rt (\%) & GR net-expt (\%) & GR RGDP (\%) \\
\hline Under 1991 Law & Minimum & -63.65 & -42.66 & -10.95 & -4.55 & -9.17 & -1094.46 & -1.97 \\
& Maximum & 180.1 & 30.34 & 40.62 & 29.17 & 268.04 & 7123.61 & 5.16 \\
& Mean & 8.6126 & 1.4929 & 7.2049 & 8.7878 & 16.7864 & 153.2943 & 0.8531 \\
& Median & 6.7793 & 0 & 4.9025 & 6.0606 & 3.7234 & 7.4136 & 0.5162 \\
& N & 39 & 39 & 39 & 39 & 39 & 39 & 39 \\
Under 1998 Law & SD & 32.2697 & 11.5537 & 10.2639 & 8.7685 & 46.844 & 1181.8482 & 1.2128 \\
& Minimum & -6.61 & -21.37 & -2.67 & -5.98 & -3.77 & -1652.25 & -18.27 \\
& Maximum & 22.97 & 27.23 & 15.37 & 10.97 & 8.27 & 68745.59 & 19.55 \\
& Mean & 5.7596 & $-4.34 \mathrm{E}-02$ & 6.2493 & 3.042 & 1.1562 & 1707.3695 & 1.599 \\
& Median & 5.0264 & -0.4963 & 6.2287 & 3.2629 & 0.6007 & 2.0961 & 1.1452 \\
Total & N & 40 & 40 & 40 & 40 & 40 & 40 & 40 \\
& SD & 6.0262 & 7.4945 & 3.6845 & 4.0638 & 2.7018 & 10875.85 & 5.3889 \\
& Minimum & -63.65 & -42.66 & -10.95 & -5.98 & -9.17 & -1652.25 & -18.27 \\
& Maximum & 180.1 & 30.34 & 40.62 & 29.17 & 268.04 & 68745.59 & 19.55 \\
& Mean & 7.1681 & 0.715 & 6.7211 & 5.8785 & 8.8724 & 940.1678 & 1.2308 \\
& Median & 5.6758 & 0 & 5.8206 & 4.4146 & 1.2658 & 4.0837 & 0.8667 \\
& N & 79 & 79 & 79 & 79 & 79 & 79 & 79 \\
& SD & 22.9681 & 9.6806 & 7.6382 & 7.3534 & 33.683 & 3.9214 & 3.9214 \\
\hline
\end{tabular}

Table 5: Change in some macroeconomic ratios

\begin{tabular}{|c|c|c|c|c|c|c|c|}
\hline$\underline{\text { Regime }}$ & Units & $\mathrm{M} 2 / \mathrm{GDP}(\%)$ & $\mathrm{M} 2 / \mathrm{GDP}(\%)$ & $\begin{array}{l}\text { Credit/ } \\
\text { GDP (\%) }\end{array}$ & $\begin{array}{r}\text { GR credit/ } \\
\text { GDP }(\%)\end{array}$ & $\begin{array}{l}\text { Net expt/ } \\
\text { GDP }(\%)\end{array}$ & $\begin{array}{l}\text { GR net-expt } \\
/ \text { GDP }(\%)\end{array}$ \\
\hline \multirow[t]{6}{*}{ Under 1991 Law } & Minimum & 19.08 & -65.43 & 65.48 & -11.26 & -23.51 & -1091.01 \\
\hline & Maximum & 357.17 & 174.72 & 606.58 & 39.99 & 109.29 & 7093.04 \\
\hline & Mean & 134.7033 & 7.7657 & 203.0247 & 6.3067 & 17.398 & 151.7514 \\
\hline & Median & 88.76 & 5.8618 & 134.715 & 2.884 & 7.81 & 6.4906 \\
\hline & $\mathrm{N}$ & 40 & 39 & 40 & 39 & 40 & 39 \\
\hline & SD & 97.3954 & 31.7303 & 143.4087 & 10.157 & 27.0056 & 1176.9854 \\
\hline \multirow[t]{6}{*}{ Under 1998 Law } & Minimum & 362.85 & -11.32 & 602.21 & -8.67 & -6532.6 & -1660.45 \\
\hline & Maximum & 2139.18 & 38.81 & 4157.35 & 30.21 & 438196.81 & 68102.47 \\
\hline & Mean & 1065.8075 & 4.4545 & 1989.4238 & 4.8484 & 31006.418 & 1689.2691 \\
\hline & Median & 1083.535 & 3.6992 & 1810.93 & 4.5054 & 376.46 & 0.4886 \\
\hline & $\mathrm{N}$ & 40 & 40 & 40 & 40 & 40 & 40 \\
\hline & $\mathrm{SD}$ & 545.086 & 9.2257 & 1074.8083 & 6.4551 & 95314.844 & 10774.5397 \\
\hline \multirow[t]{6}{*}{ Total } & Minimum & 19.08 & -65.43 & 65.48 & -11.26 & -6532.6 & -1660.45 \\
\hline & Maximum & 2139.18 & 174.72 & 4157.35 & 39.99 & 438196.81 & 68102.47 \\
\hline & Mean & 600.2554 & 6.0892 & 1096.2243 & 5.5683 & 15511.908 & 930.2414 \\
\hline & Median & 360.01 & 4.6359 & 604.395 & 3.9806 & 72.98 & 2.2531 \\
\hline & $\mathrm{N}$ & 80 & 79 & 80 & 79 & 80 & 79 \\
\hline & $\mathrm{SD}$ & 608.9697 & 23.148 & 1178.2835 & 8.4636 & 68761.031 & 7701.8641 \\
\hline
\end{tabular}

confirms with some of the theoretical explanation in terms of direction of impact. For instance, monetary expansion reduces interest rate, raises credit advancement as well as the price level. Contrary to the exchange rate channels, money expansion raises exchange rate, reduces net export and consequently lowers output. Researchers 
Table 6: VAR lag order selection criteria (Endogenous variables: LNM R LNCR LNCPI E LNNX LNGDP; Exogenous variables: C; Date: 02/20/03 Time: 18:00; Sample: 1988:1 2007:4; Included observations: 76)

\begin{tabular}{|c|c|c|c|c|c|c|}
\hline$\underline{\mathrm{Lag}}$ & $\log \mathrm{L}$ & LR & FPE & $\mathrm{AIC}$ & $\mathrm{SC}$ & $\mathrm{HQ}$ \\
\hline 0 & -738.3800 & NA & 0.778905 & 19.61526 & 19.82994 & 19.70106 \\
\hline 1 & -232.2988 & 905.6189 & $4.68 \mathrm{E}-06^{*}$ & 7.586810 & $9.304193^{*}$ & $8.273159^{*}$ \\
\hline 2 & -200.7945 & 50.57262 & $7.65 \mathrm{E}-06$ & 8.047225 & 11.26732 & 9.334129 \\
\hline 3 & -134.7309 & $93.87989^{*}$ & $5.30 \mathrm{E}-06$ & 7.598182 & 12.32098 & 9.485642 \\
\hline 4 & -84.28677 & 62.39144 & $6.02 \mathrm{E}-06$ & $7.560178^{*}$ & 13.78569 & 10.04819 \\
\hline
\end{tabular}

*Indicates lag order selected by the criterion; LR: Sequential modified LR test statistic (each test at 5\% level); FPE: Final Prediction Error; AIC: Akaike Information Criterion; SC: Schwarz Information Criterion; HQ: Hannan-Quinn Information Criterion

Table 7: VAR residual serial correlation LM tests $\left(\mathrm{H}_{0}\right.$ : No serial correlation at lag order h; Date: 02/20/03; Time: 18:09; Sample: 1988:1, 2007:4; Included observations: 79

\begin{tabular}{lll}
\hline Lags & LM-stat & Probability \\
\hline 1 & 51.62537 & 0.3716 \\
2 & 98.08524 & 0.0000 \\
3 & 32.08425 & 0.9705 \\
4 & 142.5944 & 0.0000 \\
\hline
\end{tabular}

Probability from Chi-square $\left(\chi^{2}\right)$ with $49 \mathrm{df}$

Table 8: Vector autoregression estimates (Date: 02/20/03; Time: 18:08; Sample (adjusted): 1988:2, 2007:4; Included observations: 79 after adjusting endpoints. Standard errors in () and t-statistics in [ ]

\begin{tabular}{|c|c|c|c|c|c|c|c|}
\hline & LNM & $\mathrm{R}$ & LNCR & LNCPI & $\mathrm{E}$ & LNNX & LNGDP \\
\hline \multirow[t]{3}{*}{ LNM(-1) } & 0.742571 & -0.458923 & 0.088646 & 0.030720 & 4.165247 & -3.080369 & -0.019315 \\
\hline & $(0.08113)$ & (1.12668) & $(0.02850)$ & $(0.02844)$ & $(2.83882)$ & $(1.46024)$ & $(0.01716)$ \\
\hline & [9.15264] & {$[-0.40732]$} & [3.10998] & [1.07999] & [1.46724] & {$[-2.10949]$} & {$[-1.12546]$} \\
\hline \multirow[t]{3}{*}{$\mathrm{R}(-1)$} & 0.002829 & 0.810840 & 0.001323 & -0.001406 & -0.264137 & -0.136713 & 0.000439 \\
\hline & $(0.00555)$ & $(0.07714)$ & $(0.00195)$ & $(0.00195)$ & $(0.19436)$ & $(0.09998)$ & $(0.00117)$ \\
\hline & [0.50934] & [10.5113] & {$[0.67809]$} & {$[-0.72196]$} & {$[-1.35898]$} & {$[-1.36743]$} & {$[0.37350]$} \\
\hline \multirow[t]{3}{*}{ LNCR(-1) } & 0.159228 & 0.466873 & 0.845712 & 0.041144 & 4.552639 & 2.796603 & 0.078439 \\
\hline & $(0.14552)$ & $(2.02082)$ & $(0.05112)$ & $(0.05102)$ & $(5.09174)$ & (2.61911) & $(0.03078)$ \\
\hline & [1.09421] & {$[0.23103]$} & [16.5422] & {$[0.80645]$} & [0.89412] & {$[1.06777]$} & [2.54829] \\
\hline \multirow[t]{3}{*}{ LNCPI(-1) } & 0.031972 & 0.544785 & 0.032180 & 0.998067 & 3.575577 & 0.527780 & -0.022048 \\
\hline & $(0.07089)$ & $(0.98449)$ & $(0.02491)$ & $(0.02485)$ & $(2.48057)$ & $(1.27596)$ & $(0.01500)$ \\
\hline & [0.45099] & {$[0.55337]$} & [1.29203] & [40.1559] & [1.44143] & {$[0.41363]$} & {$[-1.47027]$} \\
\hline \multirow[t]{3}{*}{$E(-1)$} & 0.000882 & -0.035547 & 0.000724 & -0.001906 & 0.690447 & 0.056189 & -0.000304 \\
\hline & $(0.00225)$ & $(0.03126)$ & $(0.00079)$ & $(0.00079)$ & $(0.07876)$ & $(0.04051)$ & $(0.00048)$ \\
\hline & {$[0.39173]$} & {$[-1.13718]$} & [0.91559] & [-2.41484] & [8.76638] & [1.38694] & {$[-0.63886]$} \\
\hline \multirow[t]{3}{*}{ LNNX(-1) } & -0.004034 & 0.179216 & 0.001703 & -0.001572 & 0.176465 & 0.087531 & 0.000222 \\
\hline & $(0.00663)$ & $(0.09208)$ & $(0.00233)$ & $(0.00232)$ & $(0.23201)$ & $(0.11934)$ & $(0.00140)$ \\
\hline & {$[-0.60831]$} & [1.94629] & {$[0.73105]$} & {$[-0.67612]$} & [0.76059] & {$[0.73344]$} & [0.15856] \\
\hline \multirow[t]{3}{*}{ LNGDP(-1) } & 0.290190 & 1.950838 & 0.113413 & -0.119960 & -14.33472 & -4.765303 & 0.788710 \\
\hline & $(0.40615)$ & $(5.64020)$ & $(0.14269)$ & $(0.14239)$ & $(14.2113)$ & $(7.31006)$ & $(0.08591)$ \\
\hline & {$[0.71449]$} & {$[0.34588]$} & {$[0.79481]$} & {$[-0.84245]$} & {$[-1.00869]$} & {$[-0.65188]$} & [9.18048] \\
\hline \multirow[t]{3}{*}{$\mathrm{C}$} & -2.287930 & -20.07244 & -0.519931 & 0.671224 & 65.00026 & 63.91411 & 1.718984 \\
\hline & $(3.71463)$ & $(51.5849)$ & (1.30504) & (1.30233) & $(129.976)$ & $(66.8573)$ & $(0.78574)$ \\
\hline & {$[-0.61592]$} & {$[-0.38911]$} & {$[-0.39840]$} & {$[0.51540]$} & {$[0.50010]$} & [0.95598] & [2.18772] \\
\hline $\mathrm{R}^{2}$ & 0.985687 & 0.706985 & 0.998351 & 0.998025 & 0.984772 & 0.454300 & 0.970728 \\
\hline Adj. $\mathrm{R}^{2}$ & 0.984276 & 0.678096 & 0.998188 & 0.997830 & 0.983271 & 0.400499 & 0.967842 \\
\hline Sum sq. resids & 2.371062 & 457.2538 & 0.292659 & 0.291443 & 2902.923 & 768.0863 & 0.106089 \\
\hline SE equation & 0.182744 & 2.537754 & 0.064202 & 0.064069 & 6.394235 & 3.289091 & 0.038655 \\
\hline F-statistic & 698.5075 & 24.47260 & 6140.662 & 5124.903 & 655.9362 & 8.444028 & 336.3621 \\
\hline Log likelihood & 26.39519 & -181.4499 & 109.0326 & 109.1971 & -254.4552 & -201.9371 & 149.1143 \\
\hline Akaike AIC & -0.465701 & 4.796199 & -2.557787 & -2.561951 & 6.644434 & 5.314863 & -3.572513 \\
\hline Schwarz SC & -0.225757 & 5.036144 & -2.317843 & -2.322007 & 6.884378 & 5.554807 & -3.332569 \\
\hline Mean dependent & 12.58765 & 20.88076 & 13.12751 & 3.221660 & 63.04810 & 10.60165 & 11.43246 \\
\hline SD dependent & 1.457337 & 4.472870 & 1.508410 & 1.375376 & 49.43712 & 4.247964 & 0.215557 \\
\hline
\end{tabular}

Determinant residual covariance: 1.96E-06; Log likelihood (df adjusted): -265.5339; Akaike information criteria: 8.140098; Schwarz criteria 9.819706

will attempt to explain this later. In terms of significance, the credit channel is validated as increase in money supply raises credit and the latter in turn impacts positively and significantly of output.

The traditional interest rate channel is in validated as monetary expansion does not significantly lower interest rate. This presents a justification for the change in sign observed under the exchange rate channels. In other words if many supply fails to impact on interest rate yet it affects net exports, it implies that it does so by increasing the price level and via the wealth effect; this raises consumption of imported goods thereby reducing net export and output. Figure 2 shows the variance decomposition charts of the variables panel 

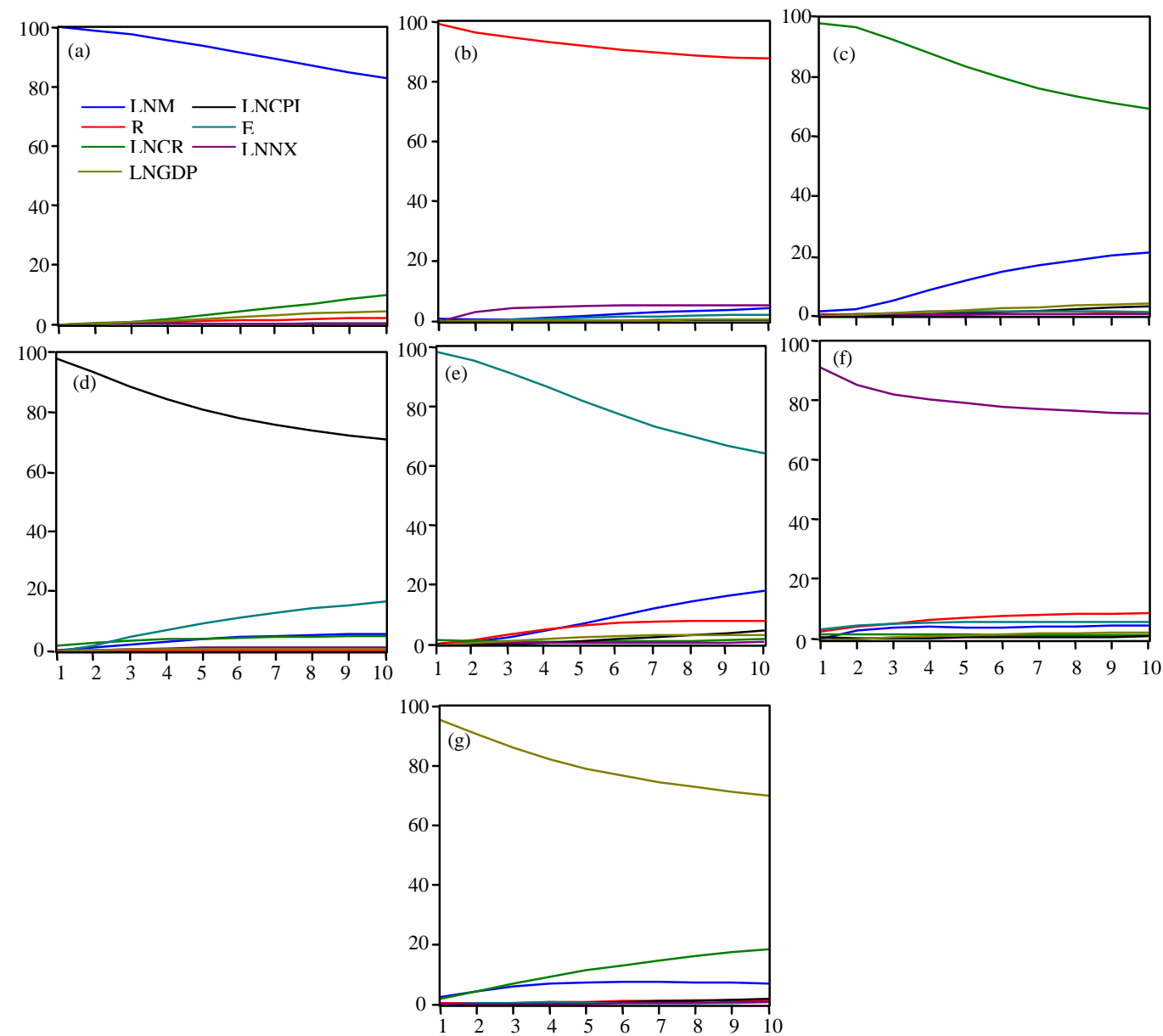

Fig. 2: Variance decomposition variance decomposition; a) LNM, b) R, c) LNCR, d) LNCPI, e) E, f) LNNX and g) LNGDP (All period)

Table 9: Vector autoregression estimates (Date: 02/20/03; Time: 18:19; Sample (adjusted): 1988:2 1997:4; Included observations: 39 after adjusting endpoints; Standard errors in () and t-statistics in []

\begin{tabular}{|c|c|c|c|c|c|c|c|}
\hline & LNM & $\mathrm{R}$ & LNCR & LNCPI & $\mathrm{E}$ & LNNX & LNGDP \\
\hline \multirow[t]{3}{*}{$\operatorname{LNM}(-1)$} & 0.747016 & -0.217273 & 0.091509 & 0.028066 & 2.853068 & -2.753422 & -0.016217 \\
\hline & $(0.12308)$ & $(1.47480)$ & $(0.04005)$ & $(0.03155)$ & $(4.05410)$ & $(1.50226)$ & $(0.00491)$ \\
\hline & [6.06913] & {$[-0.14732]$} & [2.28490] & {$[0.88964]$} & {$[0.70375]$} & [-1.83286] & {$[-3.30400]$} \\
\hline \multirow[t]{3}{*}{$R(-1)$} & -0.005795 & 0.752775 & 0.002978 & 0.001159 & -0.578895 & -0.240442 & 0.000414 \\
\hline & $(0.01325)$ & $(0.15879)$ & $(0.00431)$ & $(0.00340)$ & $(0.43650)$ & $(0.16175)$ & $(0.00053)$ \\
\hline & {$[-0.43731]$} & [4.74071] & [0.69066] & {$[0.34121]$} & {$[-1.32622]$} & [-1.48654] & {$[0.78308]$} \\
\hline \multirow[t]{3}{*}{$\operatorname{LNCR}(-1)$} & 0.322128 & -5.019682 & 0.767963 & 0.499424 & -17.58978 & -1.925307 & -0.003535 \\
\hline & $(0.52326)$ & $(6.26968)$ & $(0.17026)$ & $(0.13412)$ & $(17.2348)$ & $(6.38641)$ & $(0.02087)$ \\
\hline & {$[0.61562]$} & {$[-0.80063]$} & [4.51058] & [3.72382] & {$[-1.02059]$} & {$[-0.30147]$} & {$[-0.16942]$} \\
\hline \multirow[t]{3}{*}{ LNCPI(-1) } & -0.267018 & 5.433459 & 0.117013 & 0.650120 & 27.39659 & 0.605590 & 0.028028 \\
\hline & $(0.42943)$ & $(5.14546)$ & $(0.13973)$ & $(0.11007)$ & (14.1445) & $(5.24126)$ & $(0.01712)$ \\
\hline & {$[-0.62179]$} & {$[1.05597]$} & {$[0.83743]$} & [5.90654] & [1.93691] & {$[0.11554]$} & [1.63669] \\
\hline \multirow[t]{3}{*}{$E(-1)$} & 0.004451 & -0.071694 & 0.000304 & -0.000255 & 0.562724 & 0.100297 & -0.000186 \\
\hline & $(0.00461)$ & $(0.05527)$ & $(0.00150)$ & $(0.00118)$ & $(0.15194)$ & $(0.05630)$ & $(0.00018)$ \\
\hline & {$[0.96492]$} & {$[-1.29708]$} & {$[0.20245]$} & {$[-0.21527]$} & [3.70355] & {$[1.78140]$} & {$[-1.01250]$} \\
\hline \multirow[t]{3}{*}{$\operatorname{LNNX}(-1)$} & -0.014007 & 0.362459 & 0.006964 & 0.005628 & 0.205710 & -0.199904 & 0.000688 \\
\hline & $(0.01745)$ & $(0.20913)$ & $(0.00568)$ & $(0.00447)$ & $(0.57490)$ & $(0.21303)$ & $(0.00070)$ \\
\hline & {$[-0.80251]$} & [1.73313] & [1.22629] & [1.25806] & {$[0.35782]$} & {$[-0.93839]$} & {$[0.98795]$} \\
\hline \multirow[t]{3}{*}{ LNGDP(-1) } & 1.531329 & 3.532691 & -0.049672 & -0.259132 & -30.12696 & 15.96456 & 0.887896 \\
\hline & $(1.22735)$ & $(14.7061)$ & $(0.39936)$ & $(0.31458)$ & $(40.4260)$ & $(14.9799)$ & $(0.04894)$ \\
\hline & {$[1.24767]$} & {$[0.24022]$} & {$[-0.12438]$} & {$[-0.82373]$} & {$[-0.74524]$} & {$[1.06573]$} & [18.1409] \\
\hline \multirow[t]{2}{*}{$\mathrm{C}$} & -17.43006 & 14.70137 & 1.963724 & -2.559185 & 479.6907 & -114.3005 & 1.428819 \\
\hline & $(13.1506)$ & $(157.571)$ & $(4.27897)$ & $(3.37064)$ & $(433.150)$ & $(160.505)$ & $(0.52442)$ \\
\hline
\end{tabular}




\begin{tabular}{llllllll} 
Table 9: Continue & \multicolumn{1}{l}{} \\
\hline & LNM & $\mathrm{R}$ & LNCR & LNCPI & E & LNNX & LNGDP \\
\hline & {$[-1.32542]$} & {$[0.09330]$} & {$[0.45892]$} & {$[-0.75926]$} & {$[1.10745]$} & {$[-0.71213]$} & {$[2.72456]$} \\
$\mathrm{R}^{2}$ & 0.910806 & 0.753802 & 0.988380 & 0.995721 & 0.881103 & 0.234251 & 0.993582 \\
Adj. R & 0.890665 & 0.698209 & 0.985757 & 0.994755 & 0.854256 & 0.061340 & 0.992133 \\
Sum sq. resids & 2.127431 & 305.4316 & 0.225237 & 0.139761 & 2308.014 & 316.9110 & 0.003383 \\
SE equation & 0.261967 & 3.138890 & 0.085239 & 0.067145 & 8.628560 & 3.197333 & 0.010447 \\
F-statistic & 45.22224 & 13.55929 & 376.6991 & 1030.484 & 32.81868 & 1.354752 & 685.5911 \\
Log likelihood & 1.380005 & -95.47280 & 45.16759 & 54.47335 & -134.9099 & -96.19226 & 127.0352 \\
Akaike AIC & 0.339487 & 5.306297 & -1.906030 & -2.383249 & 7.328714 & 5.343193 & -6.104370 \\
Schwarz SC & 0.680730 & 5.647541 & -1.564787 & -2.042005 & 7.669958 & 5.684436 & -5.763127 \\
Mean dependent & 11.32707 & 21.29179 & 11.79059 & 2.024367 & 18.25128 & 7.887179 & 11.26214 \\
SD dependent & 0.792259 & 5.713775 & 0.714219 & 0.927089 & 22.60178 & 3.300151 & 0.117779 \\
\hline
\end{tabular}

Determinant residual covariance: $3.83 \mathrm{E}-07$; Log likelihood (df adjusted): -99.24486; Akaike information criteria: 7.961275; Schwarz criteria: 10.34998
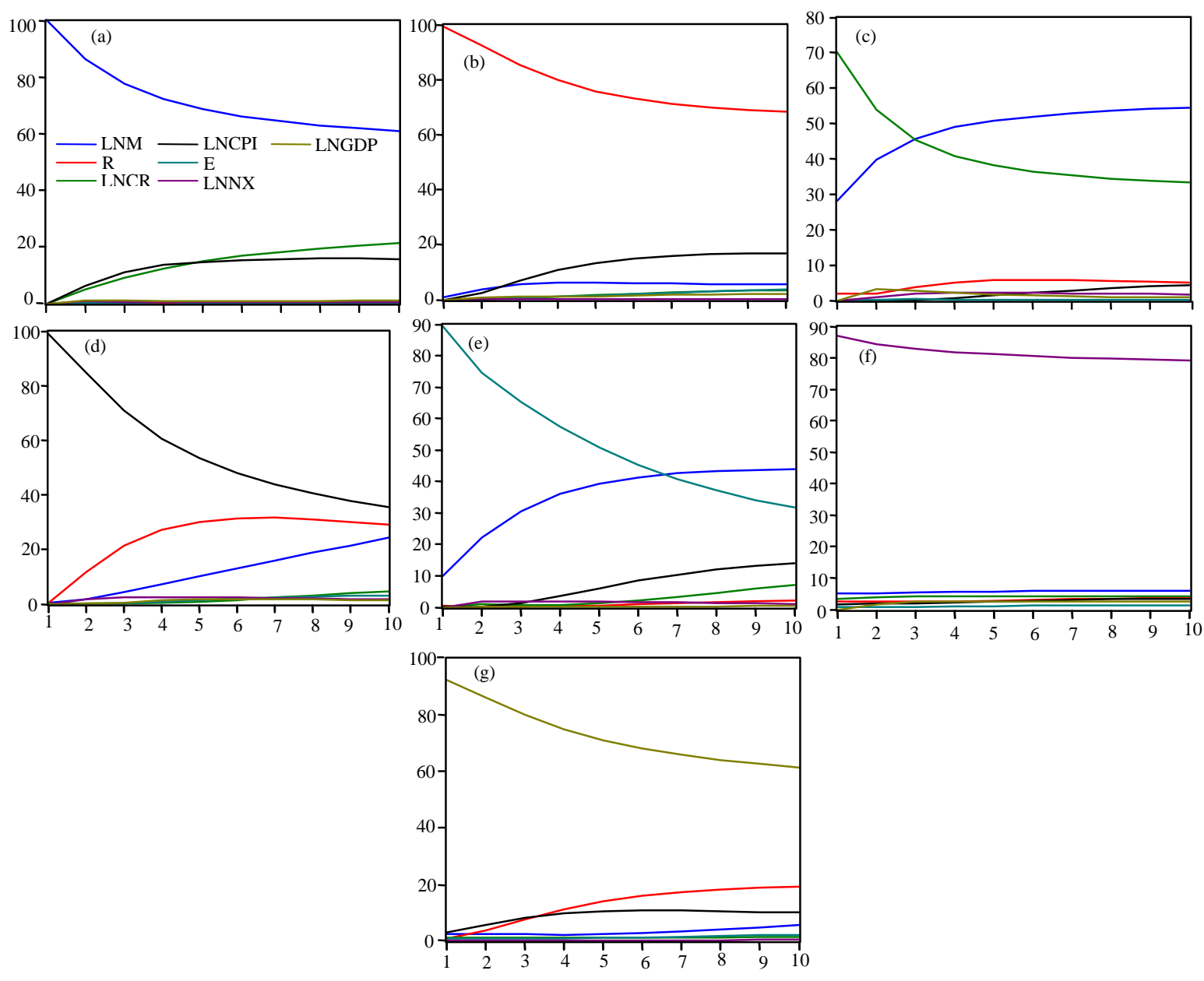

Fig. 3: Variance decomposition; a) LNM, b) R, c) LNCR, d) LNCPI, e) E, f) LNNX and g) LNGDP (1991 Act period)

shows that the change of interest rate variance responsible for by the other six variables are very small, none explain up to $10 \%$, meanwhile net export appears to dominate the other six in terms of explained variance and this percentage rises just up to period 3 after which it stabilize. In panel (c), money supply is the only variable that is gaining explanation credit which tends towards $20 \%$ as the approach 10 th period.
The path of CPI variance explained by exchange rate (panel d) is similar to that of exchange rate explainable by money supply (e) hence, we can infer that money supply influences exchange rate via its impact rather than through its impact on interest rate. In panel (g) credit advancement increasingly explained real output which underscores the credit channel of monetary transmission mechanism. 
Table 10: Vector autoregression estimates (Date: 02/20/03; Time: 18:25; Sample: 1998:1 2007:4; Included observations: 40; Standard errors in () and

\begin{tabular}{|c|c|c|c|c|c|c|c|}
\hline & LNM & $\mathrm{R}$ & LNCR & LNCPI & $\mathrm{E}$ & LNNX & LNGDP \\
\hline \multirow[t]{3}{*}{$\operatorname{LNM}(-1)$} & 0.681622 & 4.853665 & 0.234761 & 0.183651 & 15.30544 & -10.57106 & -0.041620 \\
\hline & $(0.16608)$ & $(5.38178)$ & $(0.10355)$ & $(0.11163)$ & $(8.02243)$ & $(10.7891)$ & $(0.15219)$ \\
\hline & [4.10407] & {$[0.90187]$} & {$[2.26717]$} & {$[1.64510]$} & [1.90783] & {$[-0.97979]$} & {$[-0.27347]$} \\
\hline \multirow[t]{3}{*}{$\mathrm{R}(-1)$} & -0.003171 & 0.623512 & -0.005261 & -0.007442 & 0.042891 & -0.147242 & -0.004712 \\
\hline & $(0.00417)$ & $(0.13513)$ & $(0.00260)$ & $(0.00280)$ & $(0.20143)$ & $(0.27090)$ & $(0.00382)$ \\
\hline & {$[-0.76037]$} & [4.61414] & {$[-2.02352]$} & {$[-2.65513]$} & [0.21293] & {$[-0.54352]$} & {$[-1.23318]$} \\
\hline \multirow[t]{3}{*}{$\operatorname{LNCR}(-1)$} & 0.504585 & 1.424610 & 0.821098 & -0.015979 & -5.784144 & 14.96951 & 0.084847 \\
\hline & $(0.17746)$ & $(5.75034)$ & $(0.11064)$ & $(0.11928)$ & $(8.57184)$ & $(11.5279)$ & $(0.16261)$ \\
\hline & {$[2.84340]$} & [0.24774] & [7.42138] & {$[-0.13397]$} & {$[-0.67478]$} & [1.29854] & {$[0.52177]$} \\
\hline \multirow[t]{3}{*}{ LNCPI(-1) } & -0.599953 & -8.142683 & 0.039949 & 0.638645 & -1.913532 & -2.616908 & 0.195755 \\
\hline & $(0.19789)$ & $(6.41256)$ & $(0.12338)$ & $(0.13302)$ & $(9.55899)$ & $(12.8555)$ & $(0.18134)$ \\
\hline & {$[-3.03168]$} & {$[-1.26980]$} & {$[0.32379]$} & [4.80125] & {$[-0.20018]$} & {$[-0.20356]$} & [1.07949] \\
\hline \multirow[t]{3}{*}{$E(-1)$} & 0.001692 & -0.056861 & -0.001104 & 0.000362 & 0.712056 & -0.052322 & 0.000622 \\
\hline & $(0.00230)$ & $(0.07459)$ & $(0.00144)$ & $(0.00155)$ & $(0.11118)$ & $(0.14952)$ & $(0.00211)$ \\
\hline & {$[0.73493]$} & {$[-0.76236]$} & {$[-0.76910]$} & [0.23429] & [6.40441] & {$[-0.34992]$} & [0.29478] \\
\hline \multirow[t]{3}{*}{$\operatorname{LNNX}(-1)$} & -0.001950 & 0.014975 & -0.001506 & -0.001908 & 0.146532 & 0.101035 & $3.63 \mathrm{E}-05$ \\
\hline & $(0.00260)$ & $(0.08414)$ & $(0.00162)$ & $(0.00175)$ & $(0.12542)$ & $(0.16867)$ & $(0.00238)$ \\
\hline & {$[-0.75095]$} & [0.17798] & {$[-0.93059]$} & {$[-1.09332]$} & [1.16836] & {$[0.59901]$} & {$[0.01526]$} \\
\hline \multirow[t]{3}{*}{ LNGDP(-1) } & 0.178347 & -4.082274 & -0.186939 & 0.008301 & -1.326627 & -9.150505 & 0.243617 \\
\hline & $(0.21556)$ & $(6.98513)$ & $(0.13440)$ & $(0.14489)$ & $(10.4125)$ & $(14.0034)$ & $(0.19753)$ \\
\hline & {$[0.82735]$} & {$[-0.58442]$} & [-1.39094] & {$[0.05729]$} & {$[-0.12741]$} & {$[-0.65345]$} & [1.23331] \\
\hline \multirow[t]{3}{*}{$\mathrm{C}$} & -2.353358 & 8.996946 & 1.635936 & -0.649585 & -75.04695 & 68.22880 & 7.307135 \\
\hline & $(2.28491)$ & $(74.0400)$ & $(1.42457)$ & $(1.53582)$ & $(110.369)$ & $(148.431)$ & $(2.09377)$ \\
\hline & {$[-1.02996]$} & {$[0.12151]$} & [1.14838] & {$[-0.42296]$} & {$[-0.67996]$} & {$[0.45967]$} & [3.48995] \\
\hline $\mathrm{R}^{2}$ & 0.995405 & 0.694876 & 0.998302 & 0.990991 & 0.987504 & 0.116798 & 0.913195 \\
\hline Adj. $R^{2}$ & 0.994400 & 0.628131 & 0.997931 & 0.989020 & 0.984770 & -0.076402 & 0.894206 \\
\hline Sum sq. resids & 0.089184 & 93.64367 & 0.034667 & 0.040293 & 208.0843 & 376.3521 & 0.074886 \\
\hline SE equation & 0.052792 & 1.710662 & 0.032914 & 0.035484 & 2.550026 & 3.429432 & 0.048376 \\
\hline F-statistic & 990.3483 & 10.41079 & 2688.006 & 502.8442 & 361.2592 & 0.604545 & 48.09167 \\
\hline Log likelihood & 65.36123 & -73.76989 & 84.25963 & 81.25181 & -89.73881 & -101.5905 & 68.85573 \\
\hline Akaike AIC & -2.868062 & 4.088494 & -3.812981 & -3.662591 & 4.886941 & 5.479523 & -3.042787 \\
\hline Schwarz SC & -2.530286 & 4.426270 & -3.475206 & -3.324815 & 5.224717 & 5.817299 & -2.705011 \\
\hline Mean dependent & 13.81672 & 20.48000 & 14.43101 & 4.389021 & 106.7250 & 13.24825 & 11.59852 \\
\hline SD dependent & 0.705469 & 2.805233 & 0.723571 & 0.338638 & 20.66338 & 3.305483 & 0.148729 \\
\hline
\end{tabular}

Determinant residual covariance: 9.78E-10; Log likelihood (df adjusted): 17.59824; Akaike information criteria: 1.920088; Schwarz criteria: 4.284519; Meanwhile for ease of exposition, relevant deductions are extracted and shown in Table 11

Regulation versus monetary transmission channels: The results of analysis on the period when the CBN operates under the 1991 Act are shown in Table 9 and Fig. 3. On the other hand, those within the 1998 Act are shown in Table 10 and Fig. 4. Panel A of Table 11 compares the VAR results in terms of coefficient, magnitude, significance and conformity with a prior expectation panel $\mathrm{B}$ on the other hand compares the magnitude, relation contribution and trend of variance each of the relevant path.

From panel $\mathrm{A}$, the interest rate channel is unobserved in both periods, also the nature of relationship expected is violated. Nonetheless from the coefficients magnitude, this channel is stronger in the 2 nd period. Aside from the link between exchange rate and net export in the 1st period, exchange rate channel is also not validated. The equity price channel is partly validated in both periods and with higher influence in the second period. The latter is also true of the credit channel.

The Hausman Specification Test evaluates the superiority of second period channels against that of 1 st period, its insignificance depicts no difference between the two periods in terms of monetary transmission mechanism. From panel B, it is observed from the transmission from money supply to interest rate that higher variance is explained by money supply in the 1st period, however the converse holds in the case of the transmission to output.

In the exchange rate channel, higher variance is explained in the 1st period. Equally, an examination of the equity price channel depicts that it is more relevant the 2nd period. This is also applicable to the credit channel. The results from the credit channel using the variance decomposition corroborate what we find out under the $\mathrm{VAR}$ in point $\mathrm{A}$.

From the foregoing, researchers can conclude that the credit channel is the most relevant of monetary transmission mechanisms in Nigeria. That through other channels are not really significant, researchers can document a change in their relevance as a result of a change in the autonomous status of the Central Bank of Nigeria. 

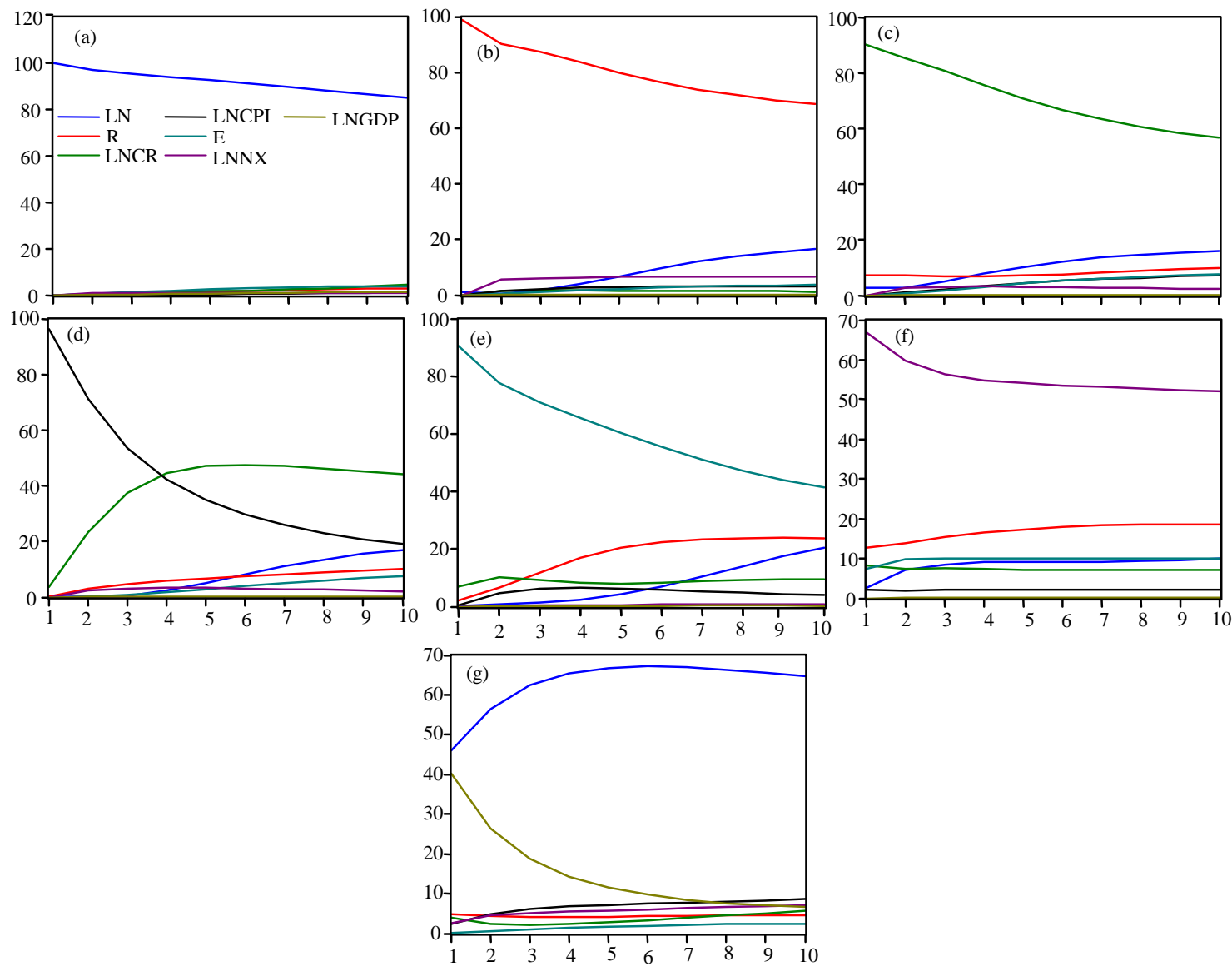

Fig. 4: Variance decomposition; a) LNM, b) R, c) LNCR, d) LNCPI, e) E, f) LNNX and g) LNGDP (1998 Act period)

\begin{tabular}{|c|c|c|c|c|c|c|c|c|}
\hline \multirow[b]{2}{*}{ Path } & \multicolumn{2}{|c|}{ A. Coefficient } & \multicolumn{2}{|l|}{ B. Magnitude } & \multicolumn{2}{|l|}{ Trend } & \multicolumn{2}{|c|}{ Relative importance } \\
\hline & 1991 & 1998 & 1991 & 1998 & 1991 & 1998 & 1991 & 1998 \\
\hline $\mathrm{M} \rightarrow \mathrm{R}$ & $-0.22^{+}$ & $4.85^{-}$ & $\begin{array}{l}\text { Tends to } \\
20 \%\end{array}$ & Tend to $5 \%$ & Above others & $\begin{array}{l}\text { As others } \\
\text { below CPI }\end{array}$ & Rising & $\begin{array}{l}\text { Rising and stable } \\
\text { at } 5 \%\end{array}$ \\
\hline $\mathrm{R} \rightarrow \mathrm{Y}$ & 0.0004 & $-0.01^{+}$ & Tend to $5 \%$ & Tend to $20 \%$ & As others below M & Above others & Stable & Rising \\
\hline $\mathrm{R} \rightarrow \mathrm{E}$ & -5.58 & 0.04 & $\begin{array}{l}\text { Tends to } \\
25 \%\end{array}$ & $1 \%$ & $\begin{array}{l}\text { Above others but } \\
\mathrm{M} \text { is closing up }\end{array}$ & Below others & $\begin{array}{l}\text { Rising and } \\
\text { stable at } 25 \%\end{array}$ & Stable \\
\hline $\mathrm{E} \rightarrow \mathrm{NX}$ & $0.10^{*}$ & $-0.05^{+}$ & $10 \%$ & $1 \%$ & As others below $\mathrm{R}$ & As others & Stable & Stable \\
\hline $\mathrm{NX}-\mathrm{Y}$ & $0.001^{+}$ & $0.0001^{+}$ & $5 \%$ & $1 \%$ & As others below M & below & stable & Stable \\
\hline $\mathrm{M} \rightarrow \mathrm{CPI}$ & $0.03^{+}$ & $0.18^{*+}$ & $\begin{array}{l}\text { Tends to } \\
15 \%\end{array}$ & $\begin{array}{l}\text { Tends to } \\
25 \%\end{array}$ & As others & $\begin{array}{l}\text { Above and } \\
\text { closing on } \mathrm{R}\end{array}$ & Rising & Rising \\
\hline $\mathrm{CPI} \rightarrow \mathrm{Y}$ & $0.03^{*+}$ & $0.20^{+}$ & $5 \%$ & $10 \%$ & As others below $\mathrm{M}$ & $\begin{array}{l}\text { Above others } \\
\text { except R }\end{array}$ & Stable & Rising and stable \\
\hline $\mathrm{M} \rightarrow \mathrm{CR}$ & $0.09^{*++}$ & $0.24^{* *+}$ & $\begin{array}{l}\text { Tends to } \\
15 \%\end{array}$ & $\begin{array}{l}\text { Tends to } \\
55 \%\end{array}$ & As others rises above & $\begin{array}{l}\text { Above others } \\
\text { in period } 4\end{array}$ & Rising & Rising and stable \\
\hline $\mathrm{CR} \rightarrow \mathrm{Y}$ & -0.004 & $0.09^{+}$ & Tends to $5 \%$ & $1 \%$ & As others & Below R and CPI & Rising & Stable \\
\hline
\end{tabular}

Hausman $\chi^{2}$ (Prob.): 6.38 (0.547); ${ }^{*}$ Significant; ${ }^{+}$Conform to a priori; Not conform

\section{CONCLUSION}

Monetary policy instruments are usually employed in the achievement of some macroeconomic objectives. The usage of such policy instrument requires that the monetary authority possesses and adequate knowledge of how it affects various aspects of the economy (Oyejide, 2002). In this wise, the concept of monetary transmission mechanism studies the description of the means by which the changes in monetary policy transmits into the domestic economic activities. The transmission process has been observed to vary over different economies of 
different financial structure and Central Bank autonomy. This study examines the various monetary transmission channels in Nigeria; brief allusion is 1998 CBN Act as a source of changes in the channels. The study then goes ahead to compare the transmission process in the period when the 1991 CBN Act is operational and the period when the $1998 \mathrm{CBN}$ Act is operational, the latter period been the one when the bank has higher autonomy.

Preliminary analysis shows a rising trend for all variables but interest rate and net export. The results of the VAR analysis and variance decomposition tests show that there is no significance change in the monetary transmission channels between the 2 periods. The major channel identified is the credit channel which supports the findings of Raheem (2008) and Uanguta and Ikhinde (2002). Although, this channel becomes stronger in the second period, we cannot statistically distinguish the process of monetary transmission based on the autonomy granted the Central Bank of Nigeria.

\section{REFERENCES}

Agha, A.I., N. Ahmed, Y.A. Mubarik and Y.A. Mubarik, 2005. Transmission mechanism of monetary policy in Pakistan. State Bank of Pakistan Working Papers, No. 9. http://www.sbp.org.pk/research/bulletin/2005/ Article-1.pdf.

BIS, 1998. The transmission mechanism of monetary policy in emerging market economies. BIS Policy papers No 3, http://www.bis.org/publ/plcy03.htm

Bernanke, B.S. and A.S. Blinder, 1992. The Federal funds rate and the channels of monetary Transmission. Am. Econ. Rev., 82: 901-902.

Black, J., 2002. Dictionary of Economics. Oxford University Press, New York.

Brainard, W., 1967. Uncertainty and the effectiveness of policy. Am. Econ. Rev., 57: 411-425.

CBN, 1999. Central bank of Nigeria decree No. 24 of 1991 with later amendment to 1999 and banks and other financial institution decree No. 24 of 1991 with later amendments up to 1999. CBN Press, Lagos.

Mann, M., 1969. How does monetary policy affect the economy. J. Money Credit Banking, 1: 538-548.
Mishkin, F.S., 1995. Symposium on the monetary transmission mechanism. J. Econ. Perspect., 9: 3-10.

Mishkin, F.S., 1996. The channel of monetary transmission mechanism: Lessons for monetary policy. NBER Working Paper No. 5464. http://ideas. repec.org/p/nbr/nberwo/5464.html.

Nnanna, J.O., 2002. Monetary policy and exchange rate stability a general overview. Nigerian Economic Societys, Lagos, Nigeria.

Odusola, A.F. and A.F. Akinlo, 2001. Output, inflation and exchange rate in developing countries: An application to Nigeria. Dev. Econ., 39 : 199-222.

Ojo, M.O., 1999. The role of the autonomy of the Central Bank of Nigeria in promoting macroeconomic stability. CBN Econ. Financial Rev., Vol. 38.

Oyejide, A.T., 2002. Monetary policy and its effects on the Nigerian economy. Nigerian Economic Societys, Lagos, Nigeria.

Philip, A.O., B. Amoah and M. Bawumia, 2003. An Investigation of the mechanism of monetary policy in Ghana: A Structural Vector error Correction Analysis. Bank of Ghana Working Paper WP/BOG-2003/02.

Pollard, P.S., 1993. Central bank independence and economic performance. Monetary Policy Transmission Mechanism in Namibia Bank of Namibia Working Papers. http://research.stlouis fed. org/publications/review/93/07/Bank_Jul_Aug1993. pdf.

Raheem, A.N., 2008. Monetary transmission mechanism in an open macroeconomic framework: The case study of Nigeria. M.Sc. Thesis, Department of Economics, University of Ibadan, Nigeria.

Tarawalie, A.B., 2008. Monetary policy instrument and transmission mechanism evidence from Sierra Leone. Ph.D Thesis, University of Ibadan

Taylor, J., 1995. The monetary transmission mechanism: An empirical framework. J. Econ. Perspect., 9: 11-26.

Uanguta, E. and S. Ikhinde, 2002. Monetary policy transmission mechanism in Namibia. Monetary Policy TransmissioBON Working Paper No. 2/02. http:/etheses.bham.ac.uk/2900/.

Uanguta, E. and S. Ikhinde, 2006. Monetary policy transmission mechanism in Namibia. Bank of Namibia Working Papers, No. 2/02. 